\title{
NETWORK TASKS AND ACCOUNTABILITY: A CONFIGURATIONAL ANALYSIS OF EU REGULATORY NETWORKS
}

Angel Saz-Carranza

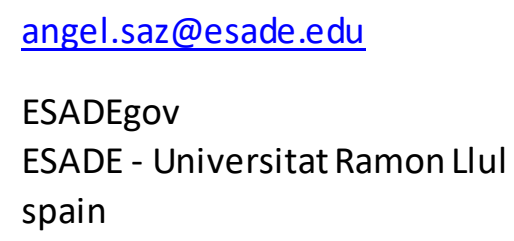

Ryan Federo

ESADE, Ramon Llull University

ESADEgeo

Barcelona

Spain

\begin{abstract}
Intergovernmental networks have become a prominent cooperative mechanism to deal with trans-boundary and interdependent problems. Yet, we still have limited knowledge of how these collaborative endeavors are governed, which is crucial to properly understanding how they function. This paper empirically examines the structural governance configurations of rule-enforcing networks in the European Union. The paper relies on data from 37 networks with rule-enforcing task and conducts a qualitative comparative analysis. We find three basic governance structure configurations used by rule-enforcing networks: first, a configuration with legal accountability, which is characterized by having a board of appeals; second, one with administrative accountability that, in addition to a board of appeals, has powerful executive boards and professional experts in the network plenary; and a third one with democratic accountability that incorporates legislative representatives in the network plenary. We argue that these results show how network tasks are related to accountability and governance.
\end{abstract}

This article has been accepted for publication and undergone full peer review but has not been through the copyediting, typesetting, pagination and proofreading process which may lead to differences between this version and the Version of Record. Please cite this article as doi: $10.1111 /$ padm. 12631 


\section{Introduction}

In a globalized interdependent world, regulation requires shared solutions and cooperation among key actors (OECD 2013). Intergovernmental networks have become a prominent type of cooperative organizational mechanism for solving trans-boundary problems emerging from our interdependent societies. The functioning of these entities is thus critical for properly tackling interdependent problems, providing effective solutions, and making good use of public resources. The functioning of an organization (or inter-organizational set) depends, in part, on its structure. More precisely, the governance structure is a key component of any organization, including regulatory networks (Coen and Thatcher 2008; Heritier and Lehmkuhl 2008). As per structuration theory, structure affects the behavior of the interrelated actors, which in turn affect the structure as they act (Giddens 1984; Kickert and Koppenjan 1997). However, we have a long way to go toward a detailed understanding of the appropriate governance configuration of intergovernmental networks. The present lack of knowledge is a barrier to understanding how these networks function and, eventually, which interventions to take to improve their effectiveness.

This paper aims to contribute to improving our empirical understanding of how intergovernmental networks work while contributing to the literature on network governance. In particular, we focus on networks with a potent but rare task: rule-enforcement. This task to ensure that stakeholders affected by a regulation comply with rules and norms is of interest because, in general, networks seldom have enforcing tasks, and even less do international networks. The significance of being delegated with such a task and its exceptionality make it a promising subject of research. Thus, in this paper, we aim to identify what are the structures of networks with rule-enforcing tasks. More specifically, our research question is: "What structural governance configurations do EU regulatory networks that are tasked with rule-enforcing have?” To answer this question, we examine the governance structure of all $37 \mathrm{EU}$ regulatory networks using qualitative comparative analysis (QCA).

Theoretically, network governance literature has underscored the importance of tasks as a key contingency factor in the design of network governance (Provan and Kenis 2008). In essence, networks that require more network-level competencies will have more integrated governance. This is so, because greater coordination is required when a network collectively enacts more complex endeavors (Kenis, Provan, and Kruyen 2009; Provan and Kenis 2008). Yet, empirical research is lacking to understand this phenomenon. 
We focus on regulatory networks and their different governance configurations. In previous research, Saz-Carranza, Salvador-Iborra, and Albareda (2016) found that, during the initial stages of a network, members negotiate in detail and bargain strongly regarding network tasks and governance mechanisms. They found that members are reluctant to delegate potent tasks to the network or to cede control points in the network's governance design. In other words, task delegation and governance complexity will occur only when they are cost-effective and inevitable (Bensaou and Venkatraman 1995; Dussauge, Garrette, and Mitchell 2000, 2004).

The EU is a fertile ground to explore networks, since many policies and areas have mixed competences (i.e., involving the EU and member states), meaning that both the EU and the member states could make policy (European Union, 2007). Moreover, the interdependence of the deeply integrated European market requires evermore regulatory harmonization among member states (Coen and Thatcher 2008). In such instances, national regulatory agencies collectively agree on a set of rules and enforce them. Rule-enforcement networks contribute to EU governance by helping members enforce laws and regulations that they have collectively determined. Aligned with Slaughter (2004; 291), we consider that EU networks have rule-enforcement tasks when they are empowered with implementation tasks. Rule-enforcement networks go beyond the basic functions of providing opinions and recommendations when drafting regulations. Rule-enforcement networks are active in implementing EU legislation and ensuring harmonization across member-states. For example, the European Banking Authority takes decisions directed at individual competent authorities or financial institutions in emergency situations, the European Medicines Agency (EMA) is in charge of authorizations of new drugs, and the European Chemicals Agency (ECHA) identifies and investigates substance of very high concern.

While recent literature on EU regulatory networks goes much beyond early studies that focused on the institutional choice between delegation to the Commission or creating an EU regulatory network (Coen and Thatcher 2008; Blauberger and Rittberger 2014; Tarrant and Kelemen 2017), few studies have looked at the internal organization structures of these networks. Maggetti and Gilardi (2011), for instance, looked at how EU member-state centrality affects the adoption of the regulations produced by the network, as well as looking at how effective these networks are in harmonizing regulations across EU member states (Maggetti and Gilardi 2014). Van Boetzelaer and Princen (2012) found that regulatory harmonization among member states depends on the level of interdependencies among them. Bach, Ruffing, and Yesilkagit (2015) showed how national regulatory 
agencies (network members) gain autonomy from their national ministries by participating in EU regulatory networks—see also Bach and Ruffing (2014) and Heims (2017). In contrast to these scholars, we look at the detailed governance structure of regulatory networks, particularly those ruleenforcing networks.

We find that rule-enforcing networks, in comparison to networks without this task, have more elaborate governance structures, combining more elements such as a board of appeals or including independent experts in the plenary. We find three basic governance structure configurations used by rule-enforcing networks: first, a configuration with legal accountability, which is mostly characterized by having a board of appeals; second, one with administrative accountability that, in addition to a board of appeals, has powerful executive boards and professional experts in the network plenary; and a third one with democratic accountability that incorporates legislative representatives in the network plenary. Importantly, we do not imply causality, but use a configurational logic to explore why several network characteristics (i.e. tasks and governance factors) tend to go together. We argue that these configurations are decided during the network setup's political negotiation among members.

The next section of the paper introduces how network administrative organizations (NAOs) are governed and structured, and the types of tasks they perform. Subsequently, the paper presents important organizational variables for rule-enforcing networks (i.e., regulatory tasks, power of executive boards, presence of boards of appeals, and representatives in the network plenary) and relates them to three accountability approaches: legal, administrative and democratic. The results of a qualitative comparative analysis conducted among $37 \mathrm{EU}$ regulatory agencies indicate that there are three groups of networks vested with rule-enforcing. The paper closes by discussing the interaction between these configurations and accountability.

\section{Goal-directed networks: governance structure and tasks}

The approach used in this research to study regulatory networks differs from previous EU regulatory network studies in that we consider regulatory networks as a subtype of interorganizational goal-directed networks. Following Provan and Kenis (2008, 231), we define interorganizational goal-directed networks as "groups of three or more legally autonomous organizations that work together to achieve not only their own goals but also a collective goal.” Scholars have studied several such networks: for example, Agranoff and McGuire (2003) studied economic development networks, Isett and Provan (2005) looked at mental health services delivery networks, 
Raab et al. (2015) examined Dutch networks managing crime prevention services, and Saz-Carranza et al. (2016) and Iborra et al. (2018) explored EU regulatory networks.

Goal-directed networks must be governed precisely because they aim to achieve a collective goal (Saz-Carranza and Ospina 2011). Specifically, the governance of goal-directed networks is "the use of institutions and resources to coordinate and control joint action across the network as a whole" (Provan and Kenis 2008, 231). Although network governance has both a behavioral and a structural dimension (Saz-Carranza and Ospina 2011), in this paper, we focus on the latter because structure affects the performance of the network as a whole and the behavior of network member. Kickert and Koppenjan's (1997) seminal work used structuration theory (Giddens 1984) to explain and illustrate how network structure and member behavior affect each other. Network behavior by the members enact and reframe the network's rules, norms, and governance structure, while modifying them marginally, but simultaneously the network’s structure constrains behavior (Kickert et al. 1997).

We focus on the governance structure because it has been far less researched up until now. The qualitative case-based approach research, which has populated the field so far, has mostly focused on behavior. The work on network activities (e.g. framing, synthesizing, activating, and so forth) illustrates the predominance of studies researching behavior (Agranoff 2006; Huxham and Vangen 2000; Saz-Carranza and Ospina 2011). However, it is important to highlight few studies that have looked at the structural forms of network governance drawing on large or even medium-sized $\mathrm{N}$ samples. Raab et al. (2015) looked, among other things, at the relationship between effectiveness and governance type (NAO vs lead organization) ${ }^{1}$ of Dutch mandated information-sharing networks in the field of crime prevention. Kenis et al. (2009) conducted a meta-analysis of network research and found no relationship between task (whether exploitative/explorative and/or ambiguous/unambiguous) and governance form. Saz-Carranza et al. (2016) found in a qualitative study of regulatory networks that members strongly attempt to influence, and bargain vigorously over, the mechanisms to be used to control the NAO's executive component, the size of the NAO's executive component, and network purpose. Iborra et al. (2018) found that rule-enforcing regulatory networks and those regulating the

1 There are three ideal structural forms of governance for whole goal-directed networks: shared governance among all network members, governance by one of the members (i.e., lead organization), and delegation of governance to a NAO (Provan and Kenis 2008). Provan and Kenis (2008) also identified the key predictors of forms of network governance, namely trust density, number of participants, goal consensus, and need for network-level competencies. In essence, low trust density, low consensus, large membership, and the need for network-level competencies all increase transaction costs (Williamson 1975) related to governing the network, thus making a central broker far more efficient than unbrokered multilateral coordination and implementation. 
economic and financial sector have more complex NAOs. Wang (2016) studied NAO-governed neighborhood networks in Beijing and found that in weaker socio-economic contexts effective networks are more relationally centralized. In this paper, we focus on a related topic, by particularly exploring what are the governance structural characteristics of the NAOs of regulatory networks with rule-enforcing task.

\section{NAO structures and accountability}

All NAOs have a plenary—a governance board, general assembly, or equivalent—which brings together all network members and is the network's highest decision-making body (Agranoff 2007; Graddy and Chen 2006; Rodriguez et al. 2007). Some NAOs have an additional board, usually called an executive or administrative board. When this board exists, it is usually charged with the detailed and continuous oversight of the NAO executive staff. Decision making among the NAO's multiple principals (Miller, 2005) and their relationship with their broker, the NAO's management, and staff, is central to the NAO's functioning.

Arguably, the plenary and boards where members meet and interact is an instance of network interaction among members rather than a structural unit of the NAO. However, we conceptualize the plenary and the board as part of the NAO since, as any other organization, it has certain "corporate" governance units, which are central to its functioning and being. In any case, the plenary and board are governance units of the network, irrespective of whether we consider them part of the NAO or not (Saz-Carranza et al. 2016).

The plenary—and the executive board, when it exists—is expected to provide resources, and safeguard accountability by controlling and monitoring both the overall endeavor as a whole and the network broker, i.e. the NAO executive staff (Davis 2005). Additionally, as is the case for public and nonprofit organizations, the plenary and board are also concerned with simultaneously combining different political standpoints and social preferences in the decision-making process (Hinna and Scarozza 2015; Blair and Stout 1999; Rajan and Zingales 2000). Figure 1 shows the NAO prototype with its basic structural units (Saz-Carranza et al. 2016).

Figure 1: NAO structure 


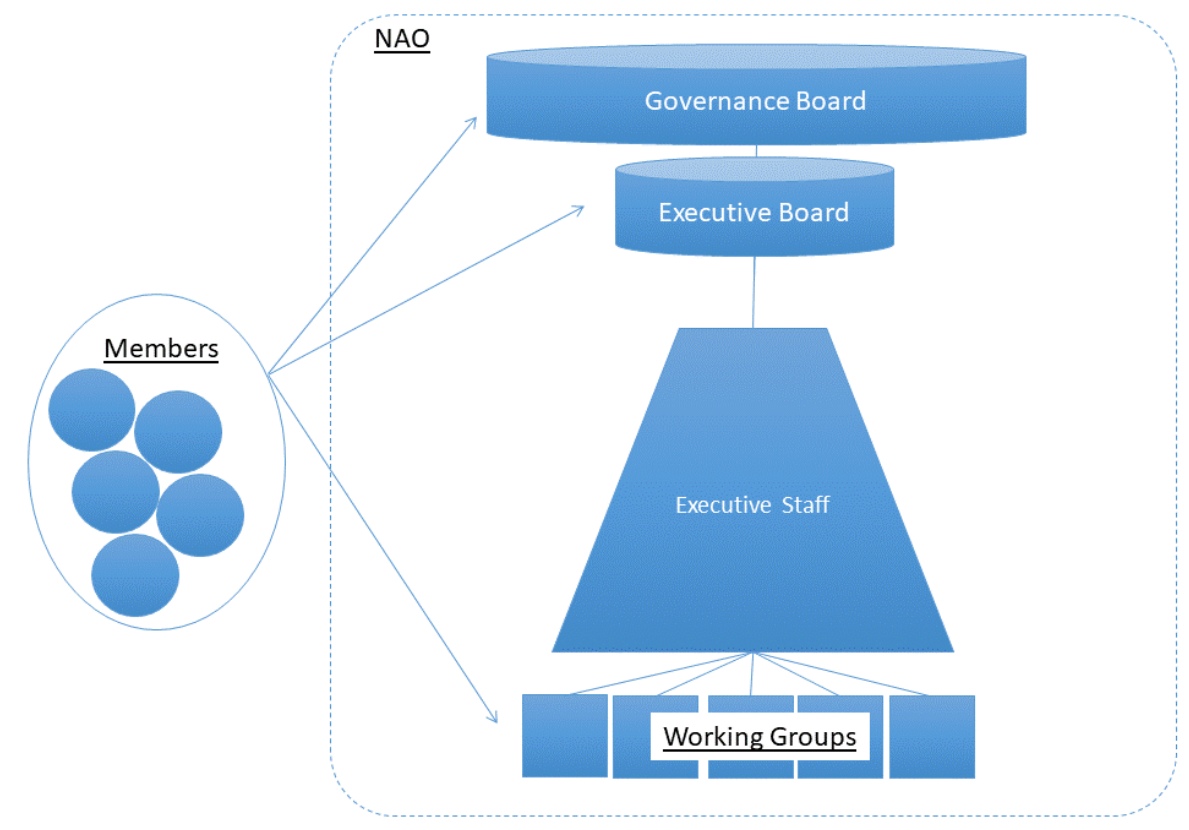

NAOs may also incorporate a board of appeals or similar body. A board of appeals-an independent unit part of the network's governance structure-is responsible for deciding on appeals against certain decisions taken by the network. The unit is independent in the sense that it is not subordinate to the plenary nor the executive component of the NAO. As an illustration, the European Securities Market Agency (ESMA) has a board of appeals composed of 6 individual independent experts (plus six alternates). This board has to decide on appeals against a decision of ESMA submitted by any natural or legal person, including competent authorities (ESMA, 2018). This "expost” accountability mechanism is particularly relevant in regulatory networks to provide and ensure fair and proportionate treatment of regulatees (Villard Duran 2015). Hence, NAOs may be more or less elaborate, including more or less highly developed administrative and governance components.

The governance structure of a network has important implications for, among other things, accountability. Accountability may be construed as "the obligation to give an account of one's actions to someone else, often balanced by a responsibility of that other to seek an account” (Scott 2006, 175; Koliba, Mills and Zia 2011). In networks, accountability between that “someone” and the "other" can refer to different actors. More specifically, the network as a whole can be externally accountable to elected politicians or to those affected by its policies and regulations. In such instances, it is the network that is accountable, and the recipient of the accountability are external 
actors. Yet, accountability can also be internal to the network, in particular when the NAO's staff is accountable to the executive component which is, in turn, accountable to the network members.

Related to this, prior research has identified various forms of accountability. In this paper, we focus on three distinct types: democratic, administrative and legal accountability. A democratic approach to accountability is a public entity (including a network) being accountable to elected officials, who have the capacity to scrutinize and influence the action of the public entity (McGravey 2001; Koliba et al. 2011). An administrative approach (or shareholder [Koliba et al. 2011]) refers to an agent being accountable to the principals, as when a public executive agency is accountable to the minister, i.e. its political minister. This is akin to how corporate governance scholars use accountability: the reporting and controlling flows connecting management to the board to shareholders (OECD 2004). In a network setting, this applies to the NAO's staff being accountable to network members (either in the executive board or in the plenary). Moreover, Koliba et al. (2011) also relate administrative accountability with expertise and professionalism. That is, following Romzek and Dubnick's (1987) framework, administrative accountability also entails structures that rely on the "skills and expertise of professionals to inform sound judgement and discretion” (Koliba et al. 2011, 213). Lastly, another approach is the legal accountability (McGravey 2001), where an external independent body is in charge of audits and evaluations - as is the case for auditors or independent evaluation offices. ${ }^{2}$ In regulatory settings, a legal accountability is often adopted when a third-party board of appeals can review decisions affecting a regulatee.

\section{Rule enforcing networks and NAO structure}

In this study, we focus on the governance configurations of networks with rule-enforcing tasks. As further discussed below, this is an important focus because it is rare that networks have ruleenforcing tasks, yet networks who have this are trusted with important competencies and thus it is necessary to unpack how they are internally organized and which accountability mechanisms do they put in place.

Public goal-directed networks are consciously created to attain specific goals and are charged with executing certain tasks to that end (Popp et al. 2014; Raab and Kenis 2009). Organizational

2 These are not the only accountability approaches identified. Other approaches (but not relevant to this study are the management approach, where results are the main accountability driver (McGarvey 2001) and the related market-based customer-oriented approach (Koliba et al. 2011). 
scholars have long related organization structure to tasks executed (Lawrence and Lorsch 1967). In this vein, Provan and Kenis (2008) identified network-level competencies as a key contingency factor of network governance forms - and while competencies are not tasks, they are a direct consequence of the tasks delegated to the network as a whole (Provan and Kenis 2008). The more of these tasks are expected, the greater the need for the NAO.

Different network tasks imply different degrees of interdependence among members (Alter and Hage 1993). Research on joint ventures and networks has found that interdependences of (network) tasks are related to how the network is governed. This is because network-level tasks imply information requirements, coordination efforts, and transaction costs (Bensaou and Venkatraman 1995; Dussauge, Garrette and Mitchell 2000, 2004; Provan and Kenis 2008). Saz-Carranza et al. (2016) proposed that operational interdependence among network members implies more elaborate and sophisticated NAOs-i.e., more governance units and larger and more diversified NAO executives.

Agranoff (2007) identified different types of public management networks that deal incrementally with exchange, concerted action, and joint production (Alter and Hage 1993). Agranoff (2007) distinguished at one end of this continuum networks that only exchange information, and at the other end interagency adjustments that formally adopt collaborative courses of action. In between, the typology positions networks that deal with information exchange, produce member services, sequence programming, exchange resource opportunities, and pool client contacts. Networks institutionalize (i.e., have larger and more complex NAOs) as they move along the continuum from exchanging information toward joint production (Agranoff 2007). Importantly, built on organization theory-based work of Alter and Hage (1993), the increasing institutionalization of collaborative ventures relates to the interdependencies implied by their purpose. Thus, joint-production networks imply far greater interdependencies than those that simply share information. Strategic alliance scholars support this: when the alliance must deliver many tasks (i.e. has a wide scope) and in particular, when it requires operational integration, a joint venture governance is preferred over a contractual alliance (Dussauge, Garrette and Mitchell 2000,).

Focusing specifically on regulatory networks, Slaughter (2004) identified three basic network functions: information sharing, rule setting, and rule enforcement. In a similar vein, and focusing on EU regulatory networks, Coen and Thatcher (2008) distinguished regulatory networks along a soft-to- 
hard continuum, which runs from coordination at the soft end to drafting secondary legislation at the EU level at the hard end. Thus, a network enforcing rules on regulated entities will have a more complex NAO than those that are simply sharing information.

All regulatory networks will, at a minimum, share information. However, not all networks are entrusted with the additional two regulatory tasks of rule setting and rule enforcement. Moreover, enforcement networks may or may not also be rule-making. In fact, Slaughter recognizes the “overlap” (p290) between these two tasks and acknowledges that "enforcement networks [help] enforce law they have individually or collectively determined"-where "collectively determined" means that the network has also set the rules (p291).

Supporting this incremental logic in the task typology, Saz-Carranza et al. (2016) found that the EU energy regulatory network Agency for the Cooperation of Energy Regulators (ACER) and the telecom Body of European Regulators for Electronic Communications (BEREC) started out with two identical proposals in terms of tasks and NAO structure. Yet, during the political negotiation related to the tasks and structures of these two networks, ACER ended up with both tasks and an elaborate NAO structure, whereas BEREC has a far slimmer governance structure and no involvement in either task (in essence being an information sharing network). European Police Office (EUROPOL), on the other hand, has rule-making capacities but not rule-enforcing ones, and has a governance structure similar to that of BEREC. Their research suggests that tasks and form of governance are interrelated and the product of political and technical rationales.

In this study, we focus on the organizational configurations that networks with rule-enforcing tasks can adopt as compared to those without this responsibility. We focus on networks with this task because it is rare that a network has such a task. In most regulatory networks, it is up to members to enforce rules. This is even more so at the international level, where implementation and enforcement are typically a matter for members to execute. Moreover, enforcement implies the highest degree of what Provan and Kenis (2008) call network-level competencies. In contrast to rule-making, which requires collective decision-making among network members, rule-enforcement requires the network to have the capacity to monitor, evaluate, and adjudicate particular cases. Importantly, while in this paper we focus on rule-enforcing networks, we do take into account whether having also rule-making tasks affects the governance structure of rule-enforcing networks. Nevertheless, we do not claim causality among the different characteristics observed. Based on previous research, we argue that 
certain characteristics are interrelated and are designed interdependently during the political negotiation of the network’s setup (Saz-Carranza et al. 2016).

\section{Governance configurations of rule-enforcing networks}

To study the structural configuration of rule-enforcing networks, we examine key organizational features of the different layers (plenary, board and other governance bodies) of such networks, as well as their tasks. The features we look into specifically cover network tasks, the presence of elected officials in the network plenary, the strength of the NAO's board, and whether the NAO includes independent experts via a board of appeals or include them in the network plenary (see Figure 2 where these features fall into the structural units of NAOs). These features are derived from the key structural components of the prototype shown in Figure 1 above and tested in a study by Iborra et al. (2018), who found that (i) network tasks are associated with NAO complexity and that (ii) the presence of elected officials and independent experts in the network plenary, the strength of the NAO's board, and whether the NAO includes a board of appeals or equivalent are all strong indicators of NAO complexity. Moreover, these structural features relate to different types of accountability, both in their approaches as in who is accountable to whom.

Figure 2: NAO prototype of regulatory networks

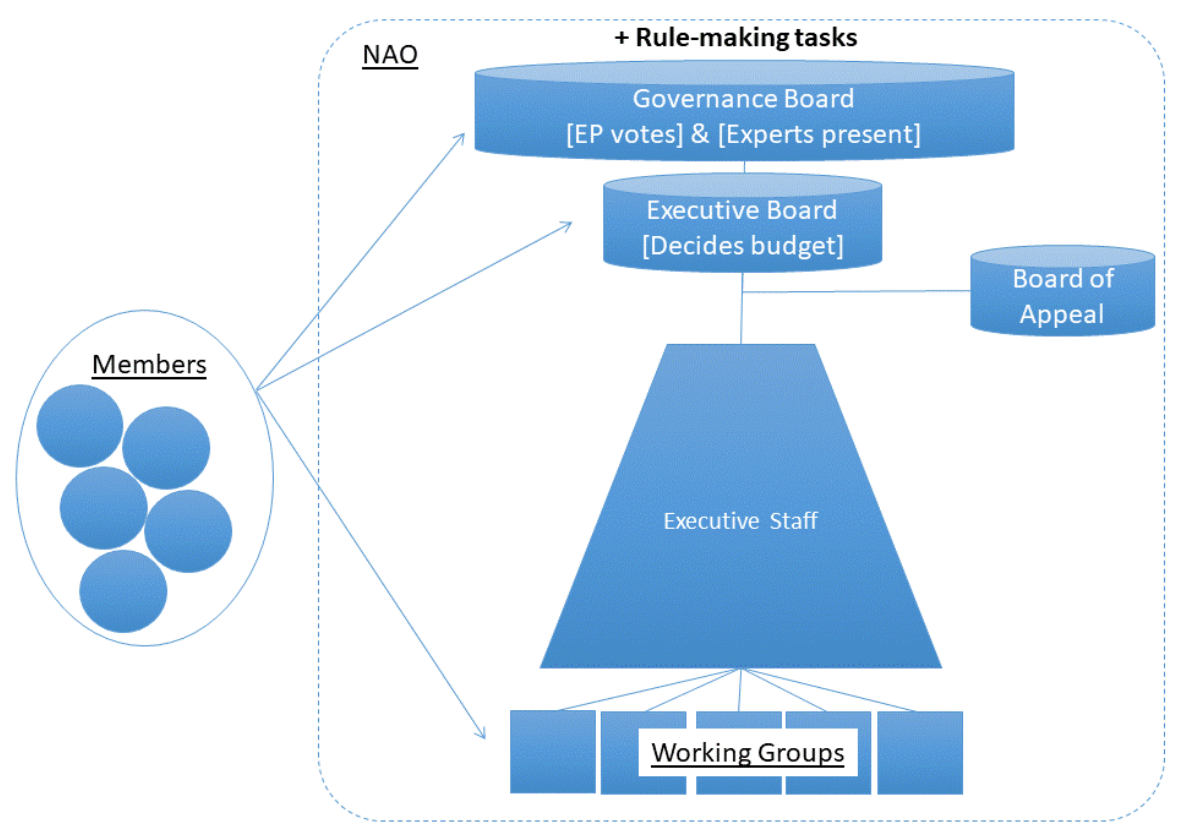


Our aim is to understand in detail the network plenary by looking at whether they include non-members such as independent experts and/or EU officials. We try to capture the second governance unit, namely the executive board — if it has one-and how powerful it is. We also look whether the network has an additional governance unit, a board of appeals, which many regulatory networks include in their design (Iborra et al. 2018). These mechanisms relate in different degrees to democratic, administrative, and legal accountability approaches. Lastly, we also explore whether the networks studied — whether with or without rule-enforcing capacities—also has rule-making powers. Together, these indicators cover all structural governance units and tasks, which are the crux of our study_Figure 3 illustrates which structural components are theoretically relevant for each accountability approach.

\section{Elected officials in the network plenary}

There are various ways of distributing control among the NAO, network members, and mandating party in mandated networks (cf. Boin, Busuoic, and Groenler 2013). Yan and Gray (1994) found that joint-venture partners negotiate to determine participation in decision making in the venture's board. In regulatory networks, a hotly contested issue is whether non-members are allowed on NAO governance bodies. More specifically, as shown by Saz-Carranza et al. (2016), members of two EU regulatory networks (BEREC and ACER) tried to increase their control over the NAO's key units and roles. In one of the regulatory networks (BEREC), the members of National Regulatory Agencies (NRAs) managed to reduce the presence of EU institution representatives on governance boards, while in the other (ACER), NRAs managed to secure unique oversight over the NAO's director-general—while having to accept representatives from the European Parliament. This is a relevant accountability issue. Perhaps the most traditional accountability mechanism in public administration is the flow from civil servants to elected officials to parliament members (McGravey 2001). Thus, a democratic accountability mechanism in regulatory networks is to place legislators in the network plenary.

It is not obvious whether to expect rule-enforcing networks to adopt a democratic accountability approach. On one hand, rule-enforcing networks are expected to require higher levels of accountability due to their potential effects on the industry and the public in general. On the other, in the European tradition, rule-enforcing agencies tend to use a legal or ex-post rather than democratic 
accountability approach (as for example police units, judicial branches or competition authorities) (Villard Duran 2015).

\section{Strong executive boards and Experts in the plenary}

The information load placed on the governance unit of an organization increases as the organization grows and/or becomes more complex (Henderson and Fredrickson 1996). This is because principals face more difficulties when attempting to capture and identify all the needs of the organization given their distance from operations. As Boivie et al. (2016) noted, in general, the larger a company is, the greater the powers of its board to cope with rising information-processing demands (Henderson and Fredrickson 2001). Similarly, for complex regulatory networks, the executive board-rather than the plenary-is the efficient governance structure to control the NAO because of its focus and proximity to the NAO’s day-to-day activities (e.g., Zahra and Pearce 1989). Among regulatory networks, we expect those networks with rule-enforcing tasks to have strong boards. Boards of networks with increasingly complex tasks will enjoy more responsibilities to better support and monitor the NAO executive. Rule-enforcing networks may be expected to have strong executive boards, boards with relevant duties, such as budget approval capacities. In this vein, executive boards that have the power to determine the budget of the network - which has clear implications for the board's operational capacity - are expected to be more present across rule-enforcing networks. In essence, networks with wider scope and greater network-level task interdependence will rely on, among others, a principals-oriented (i.e., administrative) accountability approach, which is based on the capacity of principals to exert strong measures of control over their agents (Koliba et al. 2011). 
Complex regulatory networks with rule-enforcement tasks are also likely to rely on professional and expertise-based information that cannot always be obtained in-house (Arras and Braun, 2018; Christensen and Laegreid 2007). Subsequently, networks with ruleenforcement tasks are expected to incorporate professional experts in the top decisionmaking bodies so as to have their view and opinion on the different topics that might be discussed. This emphasis on professionalism and expertise also relates with a subdimension of administrative accountability (see Koliba et al. 2011). More specifically, some regulatory networks incorporate independent experts-who are the ones to whom account is renderedin the top decision-making body, namely the plenary (Braithwaite 1999). Independent board of appeals

As mentioned previously, rule-enforcing networks may be expected to incorporate an accountability mechanism to safeguard the regulatee from abuses or errors (Villard Duran 2015). Regulatory agencies often incorporate-in addition to hands-off tools such as audit reports and performance management-independent units as accountability mechanisms (McGravey 2001). The separation of power between regulation enforcer and accountability authority relates to the legal accountability mechanism in the regulatory state, where one part of the organization (auditors, environmental compliance, consumer complaints council) oversees another part (rule-enforcing units) (Westphal 1999). Given their powers, we would expect regulatory networks empowered to implement regulations to have an appeals mechanism that would protect the regulatee from abuse or error on the part of the regulator. In other words, regulatory networks with regulation-enforcing powers will tend to use a legal accountability approach. 
Figure 3. Structural components and accountability approaches
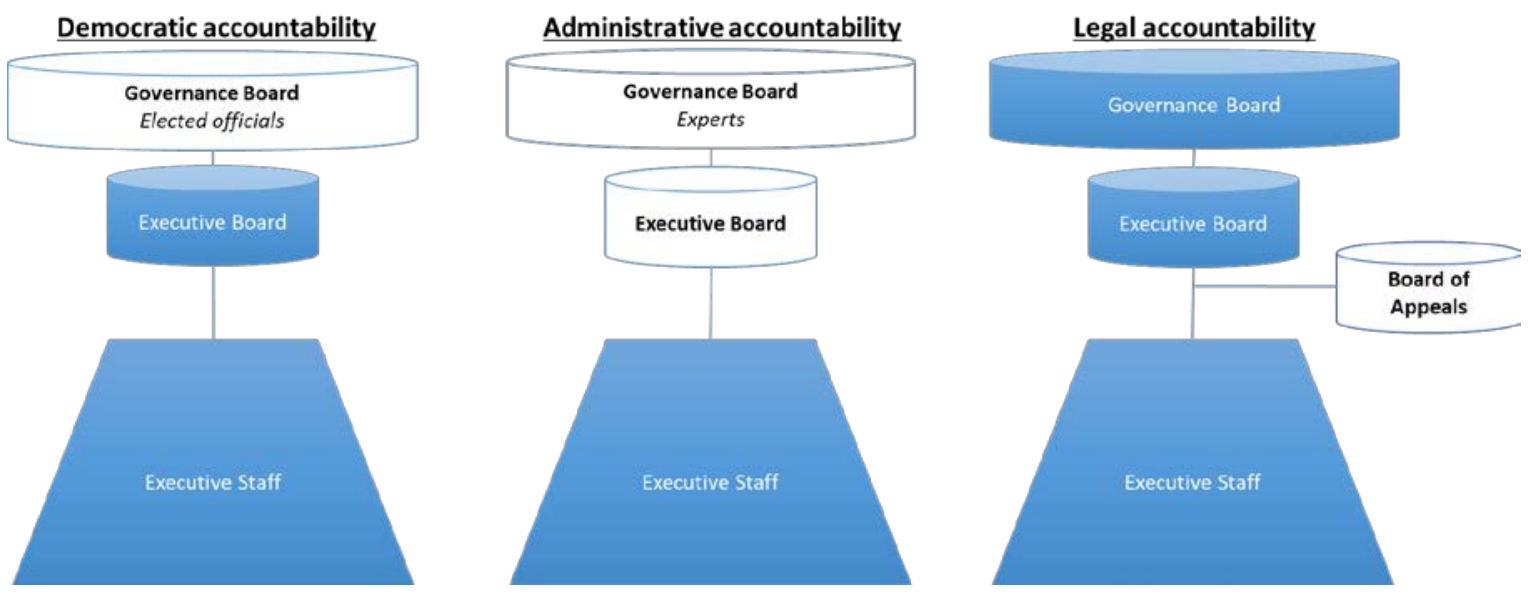

\section{Methods}

To identify different governance structures of networks, we perform an exploratory QCA facilitated by the fs/QCA software. QCA relies on set-theoretic relations rather than correlations to analyze complex relationships between different conditions and a given outcome (Fiss 2007; Ragin 2008). QCA uses Boolean algebra to combine different conditions and to identify whether the combinations of those conditions are consistently associated with an outcome (Ragin 2008). Thereby, we identify whether specific conditions are necessary and/or sufficient in configurations that are associated with the outcome of interest. QCA edges out correlation-based analyses by integrating case-based and variable-based approaches. It allows us to return to the cases, enabling us to examine the phenomenon to reveal more information about the configurations. QCA fits to our study, since this methodological approach allows us to assume and empirically explore configurational theorizing while using the tenets of causal complexity and case knowledge (Parente \& Federo, 2019) to systematically understand the governance configurations of multiple regulatory networks.

QCA has been prevalently used in prior research for configurational analysis (see reviews in: management studies by Misangyi et al. 2017; public policy by Rihoux et al. 2011; and other disciplines by Rihoux et al. 2013). The public administration field has also recognized the use of this technique to analyze complex relationships (e.g., Federo and Saz-Carranza 2018; Raab et al. 2015; Verweij, et al. 2013), including network research (e.g., Raab, Lemaire, and Provan 2013). The 
strength of QCA resides in three main features (Misangyi et al. 2017). First, QCA uses a conjunctural rationale by combining multiple conditions that are jointly associated to an outcome (Schneider and Wagemann 2012). As we theorize in this study that governance configurations of regulatory networks entail multiple interdependent conditions, QCA helps us explore the combinatory effect of different features that are associated to rule-enforcing EU regulatory networks. Second, QCA explores equifinality, which shows the possibility of different combinations of conditions that may be related to the same outcome (Katz and Kahn 1978). In this study, we assume that there are multiple paths (i.e., governance configuration) that may lead to the same outcome (i.e., having rule-enforcing tasks). In that respect, QCA serves our purpose of unveiling the different governance configurations of ruleenforcing EU regulatory networks. Third, QCA analyzes the possibility of asymmetry (BergSchlosser et al. 2009), which explores whether the inverse of the conditions in configurations that are associated to a given outcome may be related to the absence of the outcome (Misangyi et al. 2017). As we explore the governance configurations of rule-enforcing regulatory networks, QCA expands our analysis to identify also those governance configurations that are associated to regulatory networks without rule-enforcing tasks.

\section{Sample and data collection}

This paper examines $37 \mathrm{EU}$ regulatory networks. This represents the complete universe of EU regulatory networks at the time when the data collection was conducted (i.e., between 2011 and 2012). Several steps were followed to obtain this list of 37 networks. First, the authors relied on LeviFaur (2011) as well as the EU decentralized agency list (European Union, 2018) to get a complete picture of the operational regulatory networks. After excluding duplicates, we identified 86 networks, however, 17 were excluded because they were no longer operational (e.g., Committee of European Insurance and Occupational Pensions Supervisors; Committee of European Banking Supervisors; European Regulatory Group); 24 were removed because they cannot be regarded as networks following our definition, since these entities are fully controlled by the EU institutions (Parliament or Commission) and not by national regulatory members (e.g., European Asylum Support Office; European Anti-Fraud Office); finally, eight organizations were excluded because they are not regulatory in nature but rather executive and do not incorporate national regulators (e.g., Translation Centre for the Bodies of the European Union; European Centre for the Development of Vocational Training; European Global Navigation Satellite System Agency). 
Two researchers reviewed the websites and the founding documents of each network (i.e., EU regulations, by-laws, and legal statutes), and coded the conditions and the outcome included in the study. To strengthen the reliability of the codes, the researchers sorted out any inconsistency in a second round of coding. Data collection was completed during the second semester of 2012 and the information used in our analysis refers to 2011. In this respect, we acknowledge that some of the governance configurations, as well as the tasks performed by some networks, may have been amended, but this does not affect the purpose of this study.

Our outcome variable is rule-enforcement task. In that respect, we assess whether the network has the capacity to authorize regulatees. As an illustration, as stated in the acts of ACER, the network can make "binding individual decisions in specific cases and under certain conditions on cross-border infrastructure issues.” Similarly, the EMA produces evaluations of marketing authorization that are the basis for the authorization of medicines in Europe. ${ }^{3}$ In contrast, other EU regulatory agencies are more focused on sharing knowledge, information, and good practices among members (e.g., European Network for Workplace Health Promotion - ENWHP), or offering services such as training to their members (e.g., European Union Agency for Law Enforcement Training - CEPOL).

The conditions considered in the QCA are: rule-making tasks, the importance of the executive board within the network, the presence of a board of appeals, the presence of representatives of the European Parliament with the right to vote in the plenary, and the presence of independent experts in the plenary. Based on the networks' by-laws and statutes, the conditions were coded as follows:

- The first condition (i.e., rule-making tasks) indicates whether the network has the assigned task of generating proposals and providing information that will then be used by EU institutions when developing a regulation. When any of the reviewed documents mentioned that the network has the capacity to provide support or technical assistance in the development of EU legislations, it was coded as one, and as zero when this is not mentioned. As an illustration, EIOPA's website specifically states that one of the network tasks is to "give evidence-based advice to help shape informed policies and laws at the EU level."

\footnotetext{
${ }^{3}$ Another example could be the European Chemicals Agency (ECHA). According to its mission, ECHA is the driving force among regulatory authorities in implementing the EU's groundbreaking chemicals legislation for the benefit of human health and the environment as well as for innovation and competitiveness.
} 
- Second, the factor elected officials indicates whether European Parliament representatives (i.e., MEP or some of their assistants) with the right to vote in the plenary of the network. For instance, the EMCDDA has two representatives designated by the European Parliament in its main decision-making body.

- Third, the strength of the executive board within the network is measured by looking at the capacity of the board to determine the annual budget either by itself or in collaboration with the plenary meeting. For instance, the EBA executive board proposes the annual budget and also has the power to "exercise certain budgetary powers."

- The fourth condition indicates whether independent experts (i.e., individuals with expertise in the field, such as scholars or individuals with extensive professional experience) participate in the plenary of the network. As an illustration, ECHA's plenary board includes three members without voting rights appointed to represent interested parties such as people from the industry with professional experience and relevant expertise.

- Finally, the last condition merely indicates whether the network organization has a board of appeals or not.

\section{Crisp set analysis}

In line with best practices when performing QCA (Schneider and Wagemann 2012), we first analyzed for the necessity and sufficiency of each condition in configurations. Necessary conditions are those conditions that are required to be in the configurations related to an outcome, while sufficient conditions are those conditions that can be related to the outcome without the help of other conditions (Ragin 2008). A condition is considered necessary if it has a consistency score of at least 0.90 (Ragin 2006).

We then identified the sufficiency of conditions in configurations using a crisp set QCA, since our dataset consists of a binary outcome and five binary conditions. We evaluated the configurations on their consistency and frequency scores. Only those configurations that meet our consistency and frequency thresholds are taken into consideration. Consistency refers to the notion of fit between different attributes that make a configuration, in which empirical evidence supports the necessity and/or sufficiency of set theoretic relations found in the analysis (Ragin 2006). Our consistency threshold is pegged at 1.00, as we resolved contradictory configurations (Rihoux and De Meur 2008). The frequency score threshold refers to the number of cases that must be observed for 
each configuration to be considered. Our frequency threshold is one case per configuration, which is acceptable for small to medium N analyses (Federo and Saz-Carranza 2018; Haxhi and Aguilera 2016).

Those configurations that meet our consistency and frequency thresholds are presented with their respective coverage in a configuration table (Fiss 2011). Coverage measures the empirical relevance of how cases are distributed over the configurations (Ragin 2006). We report the intermediate solutions in a configuration table showing presence and absence of conditions (Ragin and Sonnet 2005). Intermediate solutions are preferred when interpreting QCA results (Ragin 2008). They only account for easy counterfactuals, which are those redundant conditions added to a set of conditions that, by itself, already related to an outcome (Fiss 2011). With 37 cases, the counterfactual analysis addresses the limited diversity of observed cases. In our analysis, only 15 configurations are observed in relation to a total of 32 possible configurations.

In presenting the configurations that emerged from the analysis, we use the following notations, proposed by Ragin and Fiss (2008): “” for the presence of the condition, “ $\otimes$ ” for the absence of the condition, and a blank space for “don't care” conditions that may be either present or absent (also understood as not relevant) in configurations. We also present the first and second level recipes by showing the core and peripheral conditions. Core conditions (larger circles) are those conditions that are taken from both parsimonious and intermediate solutions, and peripheral conditions (smaller circles) are those conditions that are eliminated in parsimonious solutions and thus only appear in intermediate solutions (Fiss 2011). Core conditions are considered definitive ingredients in the solutions, while peripheral conditions are contributing ingredients that can be removed from the solutions (Ragin and Fiss 2008).

\section{Results}

In line with the conjunctural rationale, we found no sufficient condition that by itself is always related to the presence of rule-enforcement tasks. There is also no necessary condition in the configurations. Four configurations of NAO structure for rule-enforcing networks emerged from the analysis. The solutions have an overall consistency of 1.00 and overall coverage of 1.00 (see Table 1 ).

Three configurations of NAO structure have the presence of a board of appeals as a core condition (see solutions 1, 2, and 3 in Table 1). As they share a common core condition, the 
configurations are considered as neutral permutations, which means that they differ only on contributing conditions that equally are associated with the same outcome (Fiss 2011). On the one hand, solution 1 (consistency score of 1.00 and unique coverage score of 0.22$)^{4}$ includes the presence of rule-making capacities, absence of budgetary decision-making capacities, and absence of EP voting in the plenary to complete the configuration.

On the other hand, solutions 2 and 3 (consistency scores of 1.00 and unique coverage scores of 0.11 ) both include the presence of board budgetary decision-making capacities and presence of experts in the plenary. Moreover, solution 2 includes the absence of EP voting in the plenary and rulemaking capacities is a "don't care” condition; whereas, solution 3 includes the presence of rulemaking capacities and EP voting in the plenary is a “don’t care” condition. Meanwhile, solution 4 (consistency score of 1.00 and unique coverage of 0.11) does not have a board of appeals in the configuration. The solution has rule-making capacities and EP vote as core conditions. The presence of experts in the plenary and absence of board budgetary decision-making capacities complete the configuration.

\footnotetext{
${ }^{4}$ Unique score of 0.22 means that $22 \%$ of the cases exemplify this configuration.
} 
Table 1. QCA results for rule-enforcing networks

\begin{tabular}{|c|c|c|c|c|}
\hline \multirow[b]{2}{*}{ Configurations } & \multicolumn{4}{|c|}{ Rule-enforcing networks } \\
\hline & 1 & 2 & 3 & 4 \\
\hline & Legal & \multicolumn{2}{|c|}{ Legal-Administrative } & Democratic \\
\hline (1) Network has rule-making capacities & ○ & & O & \\
\hline (2) EP has a vote at the plenary & $\otimes$ & $\otimes$ & & \\
\hline (3) The ExB determines the budget & $\otimes$ & ○ & 0 & $\otimes$ \\
\hline (4) There are experts in the plenary & & ○ & O & 0 \\
\hline (5) The NAO has a board of appeals & & & C & $\otimes$ \\
\hline Consistency & 1.00 & 1.00 & 1.00 & 1.00 \\
\hline Raw coverage & 0.22 & 0.56 & 0.56 & 0.11 \\
\hline Unique coverage & 0.22 & 0.11 & 0.11 & 0.11 \\
\hline Solution consistency & & & & \\
\hline Solution coverage & & & & \\
\hline Cases* & $\begin{array}{l}\text { CPVO } \\
\text { EASA }\end{array}$ & $\begin{array}{c}\text { ESMA } \\
\text { EBA } \\
\text { EIOPA } \\
\text { ACER } \\
\text { OHIM }\end{array}$ & $\begin{array}{c}\text { ESMA } \\
\text { EBA } \\
\text { EIOPA } \\
\text { ECHA }\end{array}$ & EMA \\
\hline
\end{tabular}

- presence of a condition; $\otimes$ - absence of a condition; "blank space” - don’t care condition (large circles are core conditions; small circles are peripheral conditions)

* Sample cases showing the configurations

We also present in Table 2 the configurations of NAOs of networks without rule-enforcement tasks. As per the concept of asymmetry, NAO structures of networks without rule-enforcement tasks do not necessarily have the inverse of the conditions of NAOs of rule-enforcing networks. We found one necessary condition in all NAO configurations of networks without rule-enforcement tasks: the absence of a board of appeals (consistency score of 1.00). Five configurations emerged from the analysis with an overall consistency score of 1.00 and overall coverage score of 1.00 . The configurations are divided into two groups: those that do not have EP voting in the plenary and those that do. 
The core conditions of those NAO configurations (see Table 2, solutions 1, 2, and 3) of networks that do not have rule-enforcement tasks are the absence of EP voting in the plenary and the absence of a board of appeals. Solution 1 (consistency score of 1.00 and unique coverage score of 0.36 ) includes the absence of budgetary decision-making capacities and absence of experts in the plenary as contributing conditions to complete the configuration. Being a rule-making network is a “don't care” condition. Solution 2 (consistency score of 1.00 and unique coverage score of 0.36 ) includes the absence of rule-making network tasks and the presence of a board with budgetary decision-making capacities as contributing conditions to complete the configuration. The presence of experts in the plenary is a “don’t care” condition. Solution 3 (consistency score of 1.00 and unique coverage score of 0.18 ) includes the presence of rule-making network tasks and presence of experts in the plenary as contributing conditions to complete the configuration. The presence of board budgetary decision-making capacities is a “don’t care” condition.

The second group of configurations (see Table 2, solutions 4 and 5) includes the presence of EP voting in the plenary as a contributing condition. Solutions 4 and 5 are neutral permutations, in which they share the absence of board of appeals and not being a rule-making network as core conditions. The absence of board budgetary decision-making capacities and presence of experts in the plenary substitute for each other in configurations of networks that do not have rule-enforcement tasks.

\section{Table 2. QCA Results for non-rule-enforcing networks}

\begin{tabular}{|c|c|c|c|c|c|}
\hline \multirow[b]{2}{*}{ Configurations } & \multicolumn{5}{|c|}{ Non-rule-enforcing networks } \\
\hline & 1 & 2 & 3 & 4 & 5 \\
\hline (1) Network has rule-making capacities & & $\otimes$ & - & $\otimes$ & $\otimes$ \\
\hline (2) EP has a vote at the plenary & $\otimes$ & $\otimes$ & $\otimes$ & - & - \\
\hline (3) The ExB determines the budget & $\otimes$ & - & & $\otimes$ & \\
\hline (4) There are experts in the plenary & $\otimes$ & & ○ & & - \\
\hline (5) The NAO has a board appeals & $\otimes$ & $\otimes$ & $\otimes$ & $\otimes$ & $\otimes$ \\
\hline Consistency & 1.00 & 1.00 & 1.00 & 1.00 & 1.00 \\
\hline Raw coverage & 0.36 & 0.36 & 0.18 & 0.07 & 0.07 \\
\hline Unique coverage & 0.36 & 0.36 & 0.18 & 0.04 & 0.04 \\
\hline Solution consistency & & & 1.00 & & \\
\hline Solution coverage & & & 1.00 & & \\
\hline
\end{tabular}




\begin{tabular}{l|ccccc}
\hline Cases* & ENWHP & CEER & EMSA & EMCDDA & EMCDDA \\
& FRONTEX & BEREC & ENISA & EEA & ECDC \\
& ECAC & IRG & EUROJUST & & \\
& EPA & IMPEL & EU-OSHA & & \\
& EEAC & EFCA & ERA & & \\
& ERGP & EUROFOU & & \\
& HMA & ND & & \\
& EUCPN & EIGE & & \\
& CEPOL & FRA & & \\
& EUROPOL & EJN & & \\
& & & \\
& &
\end{tabular}

- presence of a condition; $\otimes$ - absence of a condition; "blank space” - don’t care condition (large circles are core conditions; small circles are peripheral conditions)

* Sample cases showing the configurations

Solution 4 (consistency score of 1.00 and unique coverage score of 0.04 ) includes the absence of board budgetary decision-making capacities as another contributing condition to complete the configuration. The presence of experts in the plenary is a “don't care” condition. Solution 5 (consistency score of 1.00 and unique coverage score of 0.04) includes the presence of experts in the plenary as a contributing condition to complete the configuration. The presence of budgetary decision-making condition is a "don’t care” condition.

\section{Discussion: tasks and accountability}

In this article, we examined the relationship between network governance configurations and being vested with rule-enforcement tasks. We find three main configurations which are unique to rule-enforcing networks. Each one of the configurations follows a different accountability approach, however, they are all more likely to have rule-making capacities. This points to the cumulative nature of regulatory tasks, where the type of tasks that networks execute accumulate incrementally from information-sharing, to rule-making, through rule-enforcing (Slaughter 2004).

The three accountability approaches are: democratic, where elected officials vote in the network's plenary; pure legal, when NAOs include only a board of appeals; and legal-administrative, where-in addition to having a board of appeals—-the network's plenary includes experts and the NAO's executive reports to a strong board. In addition, we find: democratic accountability in ruleenforcing networks for whom setting rules is a core condition; pure legal accountability in ruleenforcing networks that set rules too (but not as a core condition); and legal-administrative accountability in rule-enforcing networks that may or may not include rule-making capacities . 
Interestingly, the democratic configuration (which is only represented by European Medicines Agency) is the only one among rule-enforcing networks to include rule-making as core condition. Networks with rule-making capacities require democratic oversight, since democratic accountability is specifically suitable when creating new laws and norms (Koliba et al. 2011). The other two configurations include networks that do not have rule-setting tasks as a core condition but having a board of appeals is core, hence imply, at a minimum, a legal accountability approach (McGravey 2001; Koliba et al. 2011). Rule-enforcing is about applying rules, which requires impartiality, and networks which primarily and mostly execute such tasks adopt ex-post legal accountability (Villard Duran 2015). The difference between these two configurations is that the third type also includes an element of the administrative accountability approach (i.e. a strong board and experts in the plenary), thus its name: legal-administrative. Perhaps the most important distinction of this configuration is that the three main financial (i.e., insurances, banks, and securities) regulatory networks adopt it (in addition to the chemical regulatory agency ECHA). Two possible explanations are (a) that isomorphism occurred among the three of them as they were designed in parallel (DiMaggio and Powell 1991) or (b) that the financial sector requires the board to make a greater effort to cope with organizational complexity and risks that are more critical. Finance tends to stand out as a sector requiring greater oversight boards (Federo and Saz-Carranza 2018).

In comparison to networks that are not tasked to enforce rules, our findings point to the fact that, overall, rule-enforcing networks have more elaborate governance structures. For example, ruleenforcing network configurations involve, as core condition, having a board of appeals, or having parliamentary representatives on the plenary. Configurations of networks without rule-enforcing capacities all involve the absence of a board of appeals, and those that are not setting rules also do not have parliamentary representatives on the plenary.

We believe that this paper is one of the first studies to explore the particular governance configuration of EU regulatory networks in detail, precisely from a network perspective. This we believe is important for network scholarship (Isett et al. 2011), as well as for EU regulation scholarship (Blauberger and Rittberger 2014; Coen and Thatcher 2008; Tarrant and Kelemen 2017). We complement the former by further focusing on NAOs and the specifics of network governance and accountability, particularly on how tasks relate to accountability and structural governance mechanisms. In relation to the EU regulation literature, we complement it with a more micro approach. In particular, the effectiveness and impact of EU regulatory harmonization efforts may not 
only have to do with member centrality (Maggetti and Gilardi 2011) or inter-dependencies among members (Van Boetzelaer and Princen 2012) but may also have to do with the tasks and governance structure of the regulatory network. Additionally, we open an avenue for new research on how network governance structure and tasks may affect member (i.e. NRA) autonomy (e.g. see Bach, Ruffing, and Yesilkagit 2015).

The main limitation of this paper is that it does not unpack causality. Indeed, the design and logic of this research does not allow to detail causality. Other main limitations include its regional focus on EU networks, its sectoral focus on regulatory (not executive) networks, and the fact that the methodology used is incapable of saying anything about the effect size of the relationships found. These limitations then point to future research possibilities: unravel causality, explore non-European trans-governmental networks, explore other types of public networks (beyond regulatory), and use different methodologies to study EU public networks. Notwithstanding, there is still plenty to learn about how networks deliver results in a globalized and fragmented world.

\section{References}

Agranoff R (2006) Inside collaborative networks: Ten lessons for public managers. Public Administration Review 66:56-65.

Agranoff R (2007) Managing within networks: Adding value to public organizations. Washington, DC: Georgetown University Press.

Agranoff R and McGuire M (2003) Collaborative public management: New strategies for local governments. Washington, DC: Georgetown University Press.

Alter C and Hage J (1993) Organizations working together. Newbury Park, CA: Sage.

Arras, S and Braun, C (2018) Stakeholders Wanted! Why and How European Union Agencies Involve Non-State Stakeholders. Journal of European Public Policy, 25: 1257-1275

Baysinger DB and Butler HN (1985) Corporate Governance and the Board of Directors: Performance Effects of Change in Board Composition. Journal of Law, Economics and Organization 1:101-124. 
Bach T, Ruffing E, and Yesilkagit K (2015) The Differential Empowering Effects of Europeanization on the Autonomy of National Agencies. Governance 28:285-304.

Bach T, and Ruffing E (2013) Networking For Autonomy? National Agencies In European Networks. Public Administration 91:712-726.

Bensaou M and Venkatraman N (1995) Configurations of interorganizational relationships: A comparison between U.S. and Japanese automakers. Management Science 41:1471-1492.

Berg-Schlosser D, De Meur G, Rihoux B and Ragin CC (2009) Qualitative Comparative Analysis (QCA) as an Approach. In B. Rihoux and CC Ragin (eds.) Configurational Comparative Methods. Qualitative Comparative Analysis (QCA) and Related Techniques. Thousand Oaks and London: Sage.

Blair MM and Stout LA (1999) A Team Production Theory of Corporate Law. Virginia Law Review 2:247-328.

Blauberger M and Rittberger B (2014) Conceptualizing and theorizing EU regulatory networks. Regulation \& Governance 9:367-376.

Boin A, Busuioc M, and Groenleer M (2014) Building European Union capacity to manage transboundary crises: Network or lead-agency model? Regulation and Governance 8:418-436.

Boivie, S, Bednar MK, Aguilera RV, and Andrus JL (2016) Are boards designed to fail? The implausibility of effective board monitoring. Academy of Management Annals 10:319-407.

Braithwaite J (1999). Accountability and Governance under the New Regulatory State. Australian Journal of Public Administration 58:90-94.

Christensen, T. and Laegreid, P. (2007) Regulatory Agencies-The Challenges of Balancing Agency Autonomy and Political Control. Governance. 20, 3: 499-520

Coen D and Thatcher M (2008) Network governance and multi-level delegation: European networks regulatory agencies. Journal of Public Policy 28:49-71. 
Das TK and Teng BS (2001) Trust, Control, and Risk in Strategic Alliances: An Integrated Framework. Organization Studies 22:251-283.

Davis GF (2005) New directions in corporate governance. Annual Review of Sociology 31:143-162.

DiMaggio PJ and Powell WW (1991) The New institutionalism in organizational analysis. Chicago: The University of Chicago Press.

Dussauge P, Garrette B, and Mitchell W (2000) Learning from competing partners: Outcomes and durations of scale and link alliances in Europe, North America and Asia. Strategic Management Journal 21:99-126.

Dussauge P, Garrette B, and Mitchell W (2004) Asymmetric performance: The market share impact of scale and link alliances in the global auto industry. Strategic Management Journal 25:701711.

European Securities and Markets Authority (2018) Board of Appeal. Retrieved September $9^{\text {th }}$, 2019 from https://www.esma.europa.eu/about-esma/governance/board-appeal.

European Union (2008) Consolidated version of the Treaty on the Functioning of the European Union, 13 December 2007, 2008/C 115/01.

European Union (2018) Agencies and other EU bodies. Retrieved September $9^{\text {th }} 2019$ from: https://europa.eu/european-union/about-eu/agencies en.

Federo R and Saz-Carranza (2018) A typology of board design for highly effective monitoring in intergovernmental organizations under the United Nations system. Regulation \& Governance Forthcoming. doi:10.1111/rego.12216.

Fiss PC (2007) A set-theoretic approach to organizational configurations. Academy of Management Review 32:1180-1198.

Fiss PC (2011) Building better causal theories: A fuzzy set approach to typologies in organization research. Academy of Management Journal 54:393-420. 
Giddens A (1984) The constitution of society: Outline of the theory of structuration.

Berkeley: University of California Press.

Graddy EA and Chen B (2006) Influences on the size and scope of networks for social service delivery. Journal of Public Administration Research and Theory 16:533-552.

Haxhi I and Aguilera RV (2017) An Institutional Configurational Approach to Cross-National Diversity in Corporate Governance. Journal of Management Studies 54:261-303

Heims EM (2017) Regulatory co-ordination in the EU: a cross-sector comparison. Journal of European Public Policy 24:1116-1134

Henderson A and Fredrickson J (1996) Information processing demands as determinants of CEO compensation. Academy of Management Journal 39:575-606.

Henderson A and Fredrickson J (2001) Top management team coordination needs and the CEO pay gap: A competitive test of economic and behavioral views. Academy of Management Journal 44:96-117.

Heritier A and Lehmkuhl D (2008) The shadow of hierarchy and new modes of governance. Journal of Public Policy 28:1-17.

Hinna A and Scarozza D (2015) A behavioral perspective for governing bodies: Processes and conflicts in public organizations. International Studies of Management \& Organization 45:43-59.

Huxham C and Vangen S (2000) Leadership in the shaping and implementation of collaboration agendas: how things happen in a (not quite) joined-up world. Academy of Management Journal 43:1159-1176.

Iborra SS, Saz-Carranza A, Fernández-i-Marín X, and Albareda A, (2018) The Governance of Goal-Directed Networks and Network Tasks: An Empirical Analysis of European Regulatory Networks. Journal of Public Administration Research and Theory 28: 270-292.

Isett KR, Mergel IA, LeRoux K, Mischen PA, and Rethemeyer RK (2011) Networks in public administration scholarship: Understanding where we are and where we need to go. Journal of Public Administration Research and Theory 21:157-173. 
Isett KR and Provan KG (2005) The evolution of dyadic interorganizational relationships in a network of publicly funded nonprofit agencies. Journal of Public Administration Research and Theory 15:149-165.

Jehn KA (1997) A qualitative analysis of conflict types and dimensions in organizational groups. Administrative Science Quarterly 42:530-557.

Katz D and Kahn RL (1978) The social psychology of organizations. New York: Wiley.

Kenis P, Provan KG, and Kruyen PM (2009) Network level task and the design of whole networks: Is there a relationship? Organization 8:23-40.

Kickert W and Koppenjan J (1997) Public management and network management: an overview. In W Kickert, E-H Klijn and J Koopenjan (Eds.) Managing complex networks (14-34). London: Sage.

Koliba CJ, Mills RM and Zia A (2011) Accountability in Governance Networks: An Assessment of Public, Private, and Nonprofit Emergency Management Practices Following Hurricane Katrina. Public Administration Review 71: 210-220.

Lake DA and McCubbins MD (2006) The logic of delegation to international organizations. In DG Hawkins, DA Lake, DL Nielson and MJ Tierney Delegation and Agency in International Organizations (341-368). Cambridge: Cambridge University Press.

Lawrence PR and Lorsch JW (1967) Differentiation and integration in complex organizations. Administrative Science Quarterly 12:1-30.

Levi-Faur D (2011) Regulatory networks and regulatory agencification: Towards a single European regulatory space. Journal of European Public Policy 18:810-829.

Maggetti M and Gilardi F (2011) The Policy-Making Structure of European Regulatory Networks and the Domestic Adoption of Standards. Journal of European Public Policy 18:830-847.

Maggetti M and Gilardi F (2014) Network Governance and the Domestic Adoption of Soft Rules. Journal of European Public Policy 2:1293-1310. 
McGravey N (2001) Accountability in Public Administration: A Multi-Perspective Framework of Analysis. Public Policy and Administration 16:17-29.

Miller GJ (2005) The political evolution of principal-agent models. Annual Review of Political Science 8:203-225.

Misangyi VF, Greckhamer T, Furnari S, Fiss PC, Crilly D and Aguilera RV (2017) Embracing causal complexity: The emergence of a neo-configurational perspective. Journal of Management 43:255-282.

Organisation for Economic Co-operation and Development (OECD) (2004) OECD Principles of Corporate Governance 2004. OECD.

Organisation for Economic Co-operation and Development (OECD) (2013) Principles for the governance of regulators - Public consultation draft. June 2013. Available https://goo.gl/uedstE

Parente T and Federo R (2019) Qualitative comparative analysis: Justifying a neoconfigurational approach in management research. RAUSP Management Journal Forthcoming. doi:10.1108/RAUSP-05-2019-0089.

Popp J, Milward HB, MacKean G, Casebeer A, and Lindstrom R (2014) Inter-organizational networks: A Review of the Literature to Inform Practice. Washington, DC: IBM Center for the Business of Government.

Provan KG and Kenis P (2008) Modes of network governance: Structure, management, and effectiveness. Journal of Public Administration Research and Theory 18:229-252.

Raab J and Kenis P (2009) Heading toward a society of networks: Empirical developments and theoretical challenges. Journal of Management Inquiry 18:198-210.

Raab J, Lemaire RH, and Provan KG (2013) Chapter 10 The Configurational Approach in Organizational Network Research. In Configurational theory and methods in organizational research (pp. 225-253). Emerald Group Publishing Limited. 
Raab J, Mannak RS, and Cambré B (2015) Combining structure, governance, and context: A configurational approach to network effectiveness. Journal of Public Administration Research and Theory 25:479-511.

Ragin CC and Fiss PC (2008) Net effects analysis versus configurational analysis: An empirical demonstration. In: Ragin, C.C (eds) Redesigning Social Inquiry: Set Relations in Social Research. Chicago: University of Chicago Press.

Ragin CC and Sonnett J (2005) Between Complexity and Parsimony: Limited Diversity, Counterfactual Cases, and Comparative Analysis. In: Kropp S and Minkenberg M (eds) Vergleichen in der Politikwissenschaft. VS Verlag für Sozialwissenschaften

Ragin CC (2006) Set relations in social research: Evaluating their consistency and coverage. Political Analysis 14:291-310

Ragin CC (2008) Redesigning Social Inquiry: Fuzzy Sets and Beyond. The University of Chicago Press

Rajan RG and Zingales L (2000) The Governance of the New Enterprise. NBER Working Paper No. w7958. Available at SSRN: https://ssrn.com/abstract=245587

Rihoux B and De Meur G (2008) Crisp-Set Qualitative Comparative Analysis. In: Rihoux B and Ragin C (eds) Configurational comparative methods: Qualitative comparative analysis (QCA) and related techniques Vol. 51. Sage Publications.

Rihoux B, Rezsöhazy I, and Bol D (2011) Qualitative comparative analysis (QCA) in public policy analysis: an extensive review. German Policy Studies 7:9.

Rihoux B, Álamos-Concha P, Bol D, Marx A, and Rezsöhazy I (2013) From niche to mainstream method? A comprehensive mapping of QCA applications in journal articles from 1984 to 2011. Political Research Quarterly 175-184

Rodriguez C, Langley A, Béland F, and Denis JL (2007) Governance, power, and mandated collaboration in an interorganizational network. Administration Society 39:150-193. 
Romzek BS and Dubnick MJ (1987) Accountability in the public sector: Lessons from the Challenger tragedy. Public Administration Review 47,227-238.

Iborra S, Saz-Carranza A, Fernández-i-Marín X, and Albareda A (2018) The governance of goal-directed networks and network tasks. Journal of Public Administration Research and Theory 28:270-292.

Saz-Carranza A and Ospina S (2011) The behavioral dimension of governing interorganizational goal-directed networks-managing the unity-diversity tension. Journal of Public Administration Research and Theory 21:327-365.

Saz-Carranza A, Salvador-Iborra S and Albareda A (2016) The power dynamics of mandated network administrative organizations. Public Administration Review 76:449-462.

Schneider CQ and Wagemann C (2012) Set-Theoretic methods for the social sciences: A guide to Qualitative Comparative Analysis. Cambridge: Cambridge University Press.

Scott C (2006) Spontaneous accountability. In Dowdle, MW (ed.) Public Accountability: Designs, Dilemma and Experiences (174-191). Cambridge: Cambridge University Press.

Slaughter AM (2004) Sovereignty and power in a networked world order. Stanford Journal of International Law 40:283-328.

Tarrant A and Kelemen RD (2017) Reconceptualizing European Union regulatory networks: A response to Blauberger and Rittberger. Regulation \& Governance 11:213-222.

Van Boetzelaer K and Princen S (2012) The Quest for Co-ordination in European Regulatory Networks. JCMS: Journal of Common Market Studies 50:819-836.

Verweij S, Klijn EH, Edelenbos J, and Van Buuren A (2013) What makes governance networks work? A fuzzy set qualitative comparative analysis of 14 Dutch spatial planning projects. Public Administration 91:1035-1055.

Villard Duran C (2015) The framework for the social accountability of central banks: the growing relevance of the soft law in central banking. European Journal of Legal Studies 8:97-125. 
Wang W (2016) Exploring the Determinants of Network Effectiveness: The Case of Neighborhood Governance Networks in Beijing. Journal of Public Administration Research and Theory. 26:375-388.

Westphal JD (1999) Collaboration in the Board Room: Behavioral and Performance Consequences on CEO Board Social Ties. Academy of Management Journal 42:7-24.

Williamson OE (1975) Markets and hierarchies: Analysis and antitrust implications. New York, NY: The Free Press.

Yan A and Gray B (1994) Bargaining Power, Management Control, and Performance in United States-China Joint Ventures: A Comparative Case Study. Academy of Management Journal 37:1478-1517.

Zahra SA and Pearce (1989) Boards of directors and corporate performance: A review and integrative model. Journal of Management 15:291-334. 


\section{APPENDICES}

Table A1. Presence of rule-enforcement tasks

\begin{tabular}{|c|c|c|c|c|c|c|c|c|}
\hline \multicolumn{4}{|c|}{ Conditions } & \multicolumn{2}{|c|}{ Outcome } & \multicolumn{2}{|c|}{ Consistency } & \multirow[t]{2}{*}{ Cases } \\
\hline 2 & 3 & 4 & 5 & Present & Number & Raw & PRI & \\
\hline 0 & 1 & 1 & 1 & 1 & 4 & 1 & 1 & ACER, ESMA, EBA, EIOPA \\
\hline 0 & 0 & 1 & 0 & 1 & 1 & 1 & 1 & CPVO \\
\hline 1 & 0 & 0 & 1 & 1 & 1 & 1 & 1 & EMA \\
\hline 0 & 0 & 1 & 1 & 1 & 1 & 1 & 1 & EASA \\
\hline 0 & 1 & 1 & 1 & 1 & 1 & 1 & 1 & OHIM \\
\hline 1 & 1 & 1 & 1 & 1 & 1 & 1 & 1 & ECHA \\
\hline 0 & 0 & 0 & 0 & 0 & 9 & 0 & 0 & $\begin{array}{c}\text { ENWHP, FRONTEX, ECAC, EPA, EEAC, } \\
\text { ERGP, HMA, EUCPN, CEPOL }\end{array}$ \\
\hline 0 & 1 & 0 & 1 & 0 & 8 & 0 & 0 & $\begin{array}{c}\text { CEER, BEREC, IRG, IMPEL, } \\
\text { EUROFOUND, FRA, EJN, EPRA }\end{array}$ \\
\hline 0 & 0 & 0 & 1 & 0 & 4 & 0 & 0 & EU-OSHA, ERA, ENISA, EUROJUST \\
\hline 0 & 1 & 0 & 0 & 0 & 2 & 0 & 0 & EFCA, EIGE \\
\hline 0 & 0 & 0 & 0 & 0 & 1 & 0 & 0 & EUROPOL \\
\hline 1 & 0 & 0 & 0 & 0 & 1 & 0 & 0 & EEA \\
\hline 0 & 0 & 0 & 1 & 0 & 1 & 0 & 0 & EMCDDA \\
\hline 0 & 1 & 0 & 1 & 0 & 1 & 0 & 0 & EMSA \\
\hline $0 \quad 1$ & 1 & 0 & 1 & 0 & 1 & 0 & 0 & ECDC \\
\hline
\end{tabular}


Table A2. Absence of rule-enforcement tasks

\begin{tabular}{|c|c|c|c|c|c|c|c|c|c|}
\hline \multicolumn{5}{|c|}{ Conditions } & \multicolumn{2}{|c|}{ Outcome } & \multicolumn{2}{|c|}{ Consistency } & \multirow[t]{2}{*}{ Cases } \\
\hline 1 & 2 & 3 & 4 & 5 & Absent & Number & Raw & PRI & \\
\hline 0 & 0 & 0 & 0 & 0 & 1 & 9 & 1 & 1 & $\begin{array}{c}\text { ENWHP, FRONTEX, ECAC, EPA, EEAC, } \\
\text { ERGP, HMA, EUCPN, CEPOL }\end{array}$ \\
\hline 0 & 0 & 1 & 0 & 1 & 1 & 8 & 1 & 1 & $\begin{array}{c}\text { CEER, BEREC, IRG, IMPEL, } \\
\text { EUROFOUND, FRA, EJN, EPRA }\end{array}$ \\
\hline & 0 & 0 & 0 & 1 & 1 & 4 & 1 & 1 & EU-OSHA, ERA, ENISA, EUROJUST \\
\hline & 0 & 1 & 0 & 0 & 1 & 2 & 1 & 1 & EFCA, EIGE \\
\hline & 0 & 0 & 0 & 0 & 1 & 1 & 1 & 1 & EUROPOL \\
\hline & 1 & 0 & 0 & 0 & 1 & 1 & 1 & 1 & EEA \\
\hline & 1 & 0 & 0 & 1 & 1 & 1 & 1 & 1 & EMCDDA \\
\hline 1 & 0 & 1 & 0 & 1 & 1 & 1 & 1 & 1 & EMSA \\
\hline 0 & 1 & 1 & 0 & 1 & 1 & 1 & 1 & 1 & ECDC \\
\hline & 0 & 1 & 1 & 1 & 0 & 4 & 0 & 0 & ACER, ESMA, EBA, EIOPA \\
\hline I & 0 & 0 & 1 & 0 & 0 & 1 & 0 & 0 & CPVO \\
\hline & 1 & 0 & 0 & 1 & 0 & 1 & 0 & 0 & EMA \\
\hline & 0 & 0 & 1 & 1 & 0 & 1 & 0 & 0 & EASA \\
\hline 0 & 0 & 1 & 1 & 1 & 0 & 1 & 0 & 0 & OHIM \\
\hline & 1 & 1 & 1 & 1 & 0 & 1 & 0 & 0 & ECHA \\
\hline
\end{tabular}


Table A3. Networks Included in the Analysis

\begin{tabular}{|c|c|c|c|c|c|c|}
\hline Sector & Networks & $\begin{array}{l}\text { Year of initial } \\
\text { collaboration }\end{array}$ & $\begin{array}{c}\text { Year of } \\
\text { Establishment }\end{array}$ & Staff & $\begin{array}{l}\text { Budget } 2011 \\
(€)\end{array}$ & $\begin{array}{c}\text { Mandated / } \\
\text { Voluntary }\end{array}$ \\
\hline \multirow{4}{*}{ 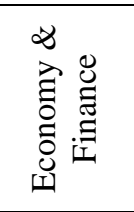 } & European Banking Authority (EBA) & 2004 & 2009 & 100 & 12683000 & Mandated \\
\hline & European Insurance and Occupational Pensions Authority (EIOPA) & 2003 & 2010 & 46 & 10667000 & Mandated \\
\hline & European Securities and Markets Authority (ESMA) & 2001 & 2009 & 101 & 16962000 & Mandated \\
\hline & $\begin{array}{l}\text { Office for Harmonization in the Internal Market (Trade Marks and Designs) } \\
\text { (OHIM) }\end{array}$ & & 1994 & 730 & 50000000 & Mandated \\
\hline \multirow{2}{*}{ 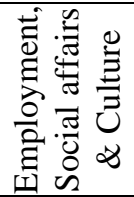 } & $\begin{array}{l}\text { European Foundation for the Improvement of Living and Working Conditions } \\
\text { (EUROFOUND) }\end{array}$ & 1975 & 1975 & 113 & 20440000 & Mandated \\
\hline & European Institute for Gender Equality (EIGE) & 2006 & 2006 & 23 & 5819800 & Mandated \\
\hline \multirow{5}{*}{ 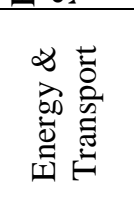 } & Agency for the Cooperation of Energy Regulators (ACER) & 2000 & 2009 & 40 & 5119000 & Mandated \\
\hline & Council of European Energy Regulators (CEER) & 2000 & 2000 & 150 & 1025000 & Voluntary \\
\hline & European Aviation Safety Agency (EASA) & 1955 & 2002 & 600 & 139554113 & Mandated \\
\hline & European Civil Aviation Conference (ECAC) & 1955 & 1993 & 14 & 2200000 & Voluntary \\
\hline & European Railway Agency - promoting safe and compatible rail systems (ERA) & 2004 & 2004 & 500 & 25983000 & Mandated \\
\hline \multirow{7}{*}{ 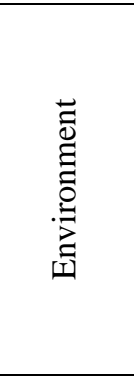 } & European Environment Agency (EEA) & 1990 & 1990 & 217 & 50330092 & Mandated \\
\hline & $\begin{array}{l}\text { European Environmental and Sustainable Development Advisory Councils } \\
\text { (EEAC) }\end{array}$ & 1990 & 1993 & $\mathrm{n} / \mathrm{a}$ & $\mathrm{n} / \mathrm{a}$ & Voluntary \\
\hline & Community Plant Variety Office (CPVO) & 1995 & 1995 & 43 & 12000000 & Mandated \\
\hline & European Fisheries Control Agency (EFCA) & 2005 & 2005 & 56 & 11013000 & Mandated \\
\hline & European Maritime Safety Agency (EMSA) & 2002 & 2009 & 101 & 16962000 & Mandated \\
\hline & $\begin{array}{l}\text { European Union Network for the Implementation and Enforcement of } \\
\text { Environmental Law (IMPEL) }\end{array}$ & 1990 & 1992 & 1 & 726000 & Voluntary \\
\hline & Network of the Heads of Environment Protection Agencies (EPA) & & 2003 & 1 & $\mathrm{n} / \mathrm{a}$ & Voluntary \\
\hline \multirow{3}{*}{ 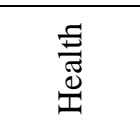 } & European Agency for Safety and Health at Work (EU-OSHA) & 1994 & 1994 & 70 & 15372768 & Mandated \\
\hline & European Network for Workplace Health Promotion (ENWHP) & 1996 & 1996 & 6 & 1085155 & Voluntary \\
\hline & European Medicines Agency (EMA) & 1995 & 2002 & 600 & 208863000 & Mandated \\
\hline
\end{tabular}

This article is protected by copyright. All rights reserved. 


\begin{tabular}{|c|c|c|c|c|c|c|}
\hline & Heads of Medicines Agencies (HMA) & 1996 & 1996 & $\mathrm{n} / \mathrm{a}$ & $\mathrm{n} / \mathrm{a}$ & Voluntary \\
\hline & European Monitoring Centre for Drugs and Drug Addiction (EMCDDA) & 1993 & 1993 & 100 & 15400000 & Mandated \\
\hline & European Centre for Disease Prevention and Control (ECDC) & 2004 & 2004 & 270 & 58107183 & Mandated \\
\hline & European Chemicals Agency (ECHA) & 2006 & 2006 & 129 & 86481700 & Mandated \\
\hline \multirow{7}{*}{ 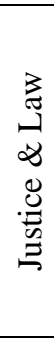 } & The European Union's Judicial Cooperation Unit (EUROJUST) & 2000 & 2002 & 186 & 31700000 & Mandated \\
\hline & European Judicial Network (EJN) & 1998 & 2001 & 5 & 522000 & \begin{tabular}{|l|l} 
Voluntary \\
\end{tabular} \\
\hline & $\begin{array}{l}\text { European Agency for the Management of Operational Cooperation at the } \\
\text { External Borders (FRONTEX) }\end{array}$ & 2004 & 2004 & 272 & 88410000 & Mandated \\
\hline & European Crime Prevention Network (EUCPN) & 2001 & 2001 & 3 & 296552 & Voluntary \\
\hline & European Police College (CEPOL) & 2005 & 2005 & 32 & 8300000 & Mandated \\
\hline & European Police Office (EUROPOL) & 1995 & 1995 & 700 & 83949000 & Mandated \\
\hline & European Union Agency for Fundamental Rights (FRA) & 2007 & 2007 & 7 & 20000000 & Mandated \\
\hline \multirow{5}{*}{ 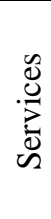 } & Body of European Regulators for Electronic Communications (BEREC) & 1997 & 2009 & 18 & 5500000 & Mandated \\
\hline & Independent Regulators Group (IRG) & 1997 & 1997 & 2 & 472500 & Voluntary \\
\hline & European Network and Information Security Agency (ENISA) & 2004 & 2004 & 47 & 8102920 & Mandated \\
\hline & European Platform of Regulatory Authorities (EPRA) & 1995 & 1995 & $\mathrm{n} / \mathrm{a}$ & $\mathrm{n} / \mathrm{a}$ & Voluntary \\
\hline & European Regulators Group for Postal Services (ERGP) & 2010 & 2010 & 2 & $\mathrm{n} / \mathrm{a}$ & Mandated \\
\hline
\end{tabular}

